\title{
LIRIK KAWIH KLININGAN GAMELAN KLASIK CICIH CANGKURILEUNG (Tilikan Struktural, Semiotik, dan Etnopedagogik)
}

\author{
Dimas Patria \\ Pos-el: kodim280990@gmail.com
}

\begin{abstract}
Abstrak
Penelitian ini berjudul "Lirik Kawih Kliningan Gamelan Klasik Cicih Cangkurileung (Tilikan Struktural, Semiotik, dan Etnopedagogik)". Penelitian ini bertujuan untuk menganalisis lirik kawih kiliningan Gamelan Klasik Cicih Cangkurileung dengan melihat unsur-unsur puisi yang ada di dalamnya serta analisis unsur semiotika dan etnopedagogik. Di dalam penelitian ini digunakan metode deskriptif. Adapun teknik yang digunakan adalah teknik wawancara, telaah pustaka, observasi, dokumentasi, dan analisis. Sumber data dalam penelitian ini adalah delapan lirik lagu kiliningan dalam album Gamelan Kalsik Cicih Cangkurileung. Penelitian ini berfokus pada analisis Struktur puisi (imaji, simbul, musikalitas atau wirahma, suasana, téma dan gaya basa), sémiotik pancacuriga (Silib, Sindir, Simbul, Siloka, dan Sasmita), dan étnopédagogik dalam moral kemanusiaan (moral manusia kepada Tuhannya, Pribadi, alam, waktu, manusia lainnya, dan menggapai kepuasan lahir batin). Hasil gambaran lirik ini menghasilkan kesimpulan, dari delapan lirik yang dianalisis strukturnya, banyak ditemukan tema mengenai keagamaan . Dalam semiotik pancacuriga, banyak ditemukan silib, simbul, dan siloka. Dalam tilikan étnopédagogik ditemukan mengenai moral manusia terhadap Tuhan dan pribadinya serta ditemukan pepatah antara lain (1) pepatah agar mau bersodakoh dan menggunakan harta di jalan yang benar, (2) pepatah agar menjadi diri yang patuh terhadap perintah agama, (3) pepatah agar mengamalkan rukun iman, (4) pepatah agar setia, (5) pepatah agar ingat kematian, dan (6) pepatah agar saling menghargai dengan orang lain.
\end{abstract}

Kata kunci: kiliningan, Cicih Cangkurileung, struktur, semiotik, etnopedagogik

\section{LYRICS OF KAWIH KLININGAN GAMELAN KLASIK CICIH CANGKURILEUNG (a Structural, Semiotics, and Ethnopedagogical Study)}

\begin{abstract}
This study entitled "Lyrics of Kawih Kliningan Gamelan Klasik Cicih Cangkurileung". This study aimed to find the elements of poetry in the lyrics of Kawih Kliningan Gamelan Klasik Cicih Cangkurileung as well as the elemental analysis of semiotics and ethnopedagogy. This study used a descriptive analytical method. The techniques covered interviews, literature review, observation, documentation, and analysis. The data source of this research is eight song lyrics on the album Gamelan Klasik Cicih Cangkurileung. The focus of this research is the analysis of poem structure (images, symbols, musicality or wirahma, atmosphere, theme, and language style), the semiotic of pancacuriga (Silib, Sindir, Simbul, Siloka, and Sasmita), and ethnopedagogy of human moral (towards God, personal, nature, time, other people, and achieving both inner and outer satisfaction). This study concludes that, of the eight lyrics, most themes are religion. In semiotic pancacuriga, this research found many silib, simbul, and siloka. From the ethnopedagogical perspective, this research found concept of human moral towards God and personal. Some proverbs were also found. They are, among others,
\end{abstract}


(1) to make alms and to use belongings on the right path, (2) to be adherent to religious orders, (3) to practice the pillars of faith, (4) to be faithful, (5) to remember death, and (6) to have mutual respect with others.

Keywords: Kliningan, Cicih Cangkurileung, Structure, Semiotics, Ethnopedagogy

\section{PENDAHULUAN}

Subang, salah satu kabupaten yang ada di Jawa Barat, kaya akan seni tradisi. Tercatat beberapa seni yang sudah dikenal, di antaranya sisingaan yang sudah terkenal ke mancanegara, toleat yang lahir dari kreativitas masyarakat Subang, dan Gembyung yang tidak lepas dari dunia pesantren. Yang tidak kalah terkenalnya, yaitu kawih kliningan. Terkenalnya kesenian ini tidak terlepas dari peran tokoh kepesindenan yang pada waktu itu terkenal hingga kancah nasional, yaitu Ibu Titim Fatimah.

Titim Fatimah adalah tokoh yang berjasa dalam mempopulerkan dunia kepesindenan. Beliau meningkatkan derajat sinden terutama dalam pagelaran wayang. Pada masanya, pamor beliau sebagai pesinden bisa mengalahkan dalang yang pada waktu itu sangatlah terkenal.

Selain Titim Fatimah, ada tokoh kepesindenan yang lain dari kabupaten Subang yang dikenal di Jawa Barat, yaitu Ibu Cicih Cangkurileung (alm). Beliau adalah ikon kepesindenan Kabupaten Subang yang memiliki ciri khas dalam senggol-senggolnya (ornamen) ketika bernyanyi. Selain itu, semasa hidupnya beliau juga aktif dalam syiar agama Islam. Album Gamelan Klasik Cicih Cangkurileung merupakan salah satu bukti karyanya dalam berdakwah dan melestarikan seni kliningan.

Danadibrata (2006, hal. 331) memaparkan bahwa kliningan berasal dari kelenengan yang memiliki arti bermain gamelan. Waditra atau alat yang dipakai dalam kliningan disebut gamelan. Gamelan sendiri dalam tradisi masyarakat Jawa diartikan sebagai alat pukul, yaitu berasal dari kata gamel (Saryoto dina Afryanto, 2014, hal. 57).

Pementasan materi kliningan salah satunya ada yang disebut dengan lagu jalan. Lagu jalan bukanlah gending yang berdiri sendiri, tetapi merupakan gending yang fungsional untuk mengiringi lagu yang dinyanyikan sinden dengan pengulangan lagu yang tidak ditentukan, tergantung persetujuan nayaga (Hernawan, 2003, hal. 47). Biasanya untuk berhenti ditandai oleh instrumen kendang.

Secara keseluruhan, lirik kawih kliningan Gamelan Klasik Cicih Cangkurileung berbentuk lirik husus, yaitu sajak. Sedangkan ada beberapa di antaranya berbentuk sair dan dangding. Tentu ini menjadi sesuatu yang sangat menarik ketika dalam satu album memiliki kekhasan sendiri terutama dalam bentuk liriknya.

Sajak, sair, dan dangding berada dalam bentuk puisi. Puisi menurut Isnendes (2010, hal. 56) adalah karangan yang bahasanya dirakit dengan penuh irama, terikat oleh diksi, pengungkapannya tidak dalam bentuk bahasa sehari-hari. Sedangkan puisi menurut Tamsyah (1996, hal. 12) adalah karangan dengan bentuk yang terikat.

Untuk memaparkan isi sajak, umumnya sajak dijelaskan unsur-unsurnya. Yang biasa dipakai untuk menganalisis unsur-unsurnya biasa disingkat ISIM (imaji, simbol, musikalitas) STG (suasana, tema, dan gaya bahasa) (Mustappa 2014, hal. 36).

Dalam membahas tanda yang ada dalam lirik, dipakai semiotik pancacuriga. Pancacuriga merupakan suatu alat untuk mengkritik (Kurniawan, 2014, hal. 4). Menurut Suryalaga (2009, hal. 68), 
pancacuriga merupakan lima alat (ilmu) untuk memaknai satu hal. Adapun lima alat tersebut adalah silib, sindir, simbol, siloka dan sasmita.

Dalam etnopedagogik, digunakan analisis melalui pembentukan karakter manusia Sunda yang pengkuh agamana, jembar budayana, luhung élmuna, dan rancagé gawéna (Moriyama, 2015, hal. 121). Penjabarannya melalui moral kemanusiaan. Adapun moral kemanusiaan yang dimaksud adalah moral manusia kepada Tuhannya, moral manusia terhadap alam, moral manusia terhadap pribadinya, moral manusia terhadap waktu, moral manusia kepada manusia lainnya, dan moral manusia dalam mencapai kepuasan lahir batin.

Dirasa bisa meningkatkan pamor lirik kawih kliningan dalam kesusastraan Sunda, tentunya harus diadakan penelitian terhadap lirik kawih kliningan Gamelan Klasik Cicih Cangkurileung. Selain itu, dengan diadakannya penelitian ini diharapkan bisa menggali nilai-nilai yang ada dalam lirik dan diharapkan bisa menjadi cerminan dalam kehidupan seharihari.

\section{METODE}

Metode yang digunakan dalam penelitian ini adalah metode deskriptif. Metode deskriptif adalah penelitian yang mempunyai tujuan untuk mengadakan pemeriksaan dan pengukuran-pengukuran terhadap suatu kejadian tertentu (Fathoni, 2006, kc. 97). Hal ini untuk mengumpulkan informasi yang faktual secara rinci dan menggambarkan hal-hal yang menjadi perhatian dalam penelitian.

Data dalalam tulisan ini adalah album Gamelan Klasik Cicih Cangkurileung. Dalam album ini terdapat delapan lagu. Adapun lagu-lagu tersebut adalah Balébat Iman, Karumaosan, Jatining Hirup, Nikmat Duriat, Pucuk Camara, Rukun Iman, Samoja Bodas, dan Sapuluh Daun. Dari delapan judul tersebut, lagu Balébat
Iman strukturnya berbentuk pupuh Kinanti. Sedangkan Nikmat Duriat berbentuk sair. Enam lagu lainnya berbentuk sajak bebas.

Instrumen yang digunakan dalam tulisan ini adalah kartu data. Kartu data digunakan untuk memudahkan dalam proses analisis. Instrumen lainnya pun digunakan dalam penelitian ini, guna mendukung hasil analisis kartu data. Adapun instrumen yang dipakai di antaranya sistem tabel ceklis untuk telaah pustaka dan observasi. Instrumen wawancara dan dokumentasi pun dibuat untuk menambah keakuratan hasil analisis.

\section{HASIL DAN PEMBAHASAN Hasil Analisis Struktur}

Album Gamelan Klasik Cicih Cangkurileung dilihat strukturnya merupakan bentuk puisi. Sebagaimana dibahas sebelumnya, dalam memaparkan isi puisi dan sajak, harus dijelaskan unsurunsurnya. Yang biasa dipakai untuk menganalisis unsur-unsurnya biasa disingkat ISIM (imaji, simbol, musikalitas) STG (suasana, tema, dan gaya bahasa) (Mustappa 2014, hal. 36).

Sebagai salah satu bentuk kawih, kliningan membarikan warna tersendiri dalam dunia kawih. Menyebut istilah kawih, kita bisa melihat dari insturmen yang digunakan dalam pengiring lagunya. (Hendrayana, 2014, hal. 36)

Berdasarkan hasil analisis struktur, ditemukan beberapa hal yang sangat menarik untuk dipaparkan. Pertama, yaitu jumlah lirik dan bai antara lirik yang satu dengan yang lainnya berbeda-beda. Dalam lagu Balébat Iman, ditemukan lirik dengan bentuk dangding pupuh kinanti. Begitupun dengan lirik Nikmat Duriat yang merupakan bentuk sair. Sedangkan sisanya ada dalam bentuk sajak bebas. Lagu Jatining Hirup, Nikmat Duriat,Rukun Iman jeung Samoja Bodas adalah lirik yang dibarengi dengan juru alok. Sedangkan empat lagu lainnya tidak dibarengi dengan juru alok. 
Imaji dalam album ini umumnya banyak ditemukan imaji penglihatan dan pendengaran. Dari setiap lirik, dua imaji ini ada. Hal ini dikarenakan pengarang menciptakan lirik ini dengan pengalamannya berapresiasi dengan indera penglihatan dan pendengarannya yang diwujudkan dalam lagu. Imaji yang ada dalam tema religius biasanya identik dengan hal-hal yang dekat dengan amal dan ganjaran serta balasannya. Peran imaji penglihatan dalam lirik ini untuk memperjelas dan memperlihatkan siksaan yang tujuannya agar yang melihat dan memperdengarkan lirik ini ada rasa ingat dan takut akan karma yang akan didapat dari perilakunya sehari-hari. Apabila dipersentasekan, terlihat seperti di gambar 1.

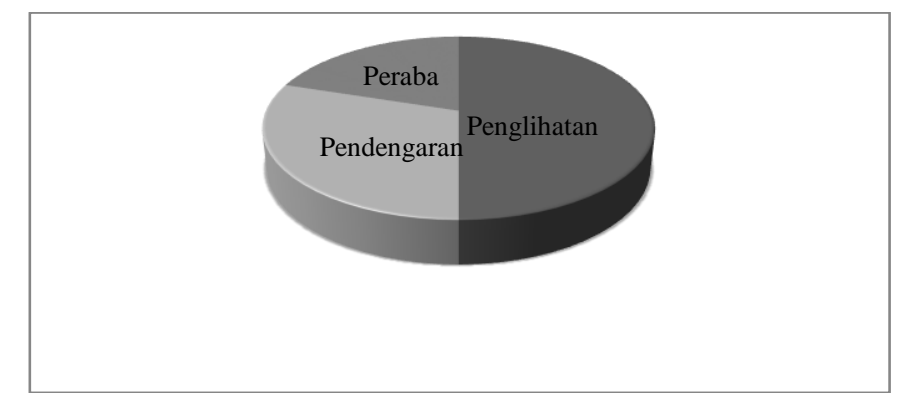

\section{Gambar 1: Diagram Imaji Lirik Kawih Kiliningan Gamelan Kasik Cicih Cangkurileung}

\begin{abstract}
Adanya imaji penglihatan yang dominan, pengarang seolah ingin memperlihatkan kepada pembaca dan pendengar bahwa segala hal yang terjadi dalam kehidupan akan memdapatkan balasan dan ganjaran dari Allah swt. Hal tersebut bisa dilihat dari beberapa lirik yang banyak membahas tentang perilaku manusia yang dianjurkan dan dilarang serta balasan serta ganjarannya apabila dilakukan.
\end{abstract}

Simbol dalam lirik ini banyak membahas perkara Gusti yang Maha Kuasa. Hal tersebut terlihat dari tema yang religius seperti dalam lagu Balébat Iman, Jatining Hirup,Karumaosan,Rukun Iman dan Samoja Bodas. Lima lagu yang disebutkan tadi sama hal yang diceritakannya yaitu perkara Tuhan, pribadi manusia, dan balasan setelah kematian. Tiga simbol tersebut selalu ditemukan dalam setiap lirik. Berbeda dengan lirik Nikmat Duriat, Pucuk Camara dan Sapuluh Daun. Simbol dalam Nikmat Duriat cukup digambarkan dengan kuring (saya) dan manéhna (dirinya) yang sedang menjalin hubungan asmara. Begitupun kisah asmara ini digambarkan dalam lirik Sapuluh Daun. Yang berbeda hanya dari suasana. Berbeda dengan lagu Sapuluh Daun. Dalam lagu ini bahasa yang digunakan tidak banyak kiasannya. Simbol yang diangkat dalam lirik ini adalah dunungan dan seniman yang harus hidup selaras dalam memajukan seni. Untuk diagram simbol akan dibahas lebih mendalam di pembahasan semiotik.

Musikalitas atau irama dalam lirik ini banyak dibangun oleh efoni konsonan $n$ dan $n g$ yang mengakibatkan lagu memenuhi sarat agar enak untuk dinyanyikan. Selain efoni, banyak pula ditemukan kakofoni yang mengakibatkan lirik kurang enak untuk dinyanyikan. Dalam hal ini pengarang ingin menonjolakeun rasa tidak nyamannya melalui gambaran kakofoni tersebut. Ungkapan kalimat dalam kakofoni menyesuaikan suasana yang digambarkan pengarang yaitu suasana sedih. Tapi walau 
demikian, semua lirik memenuhi sarat sebagai lirik yang enak untuk dijadikan lagu. Gambaran musikalitas dalam album ini bisa dilihat dari gambar 2 .

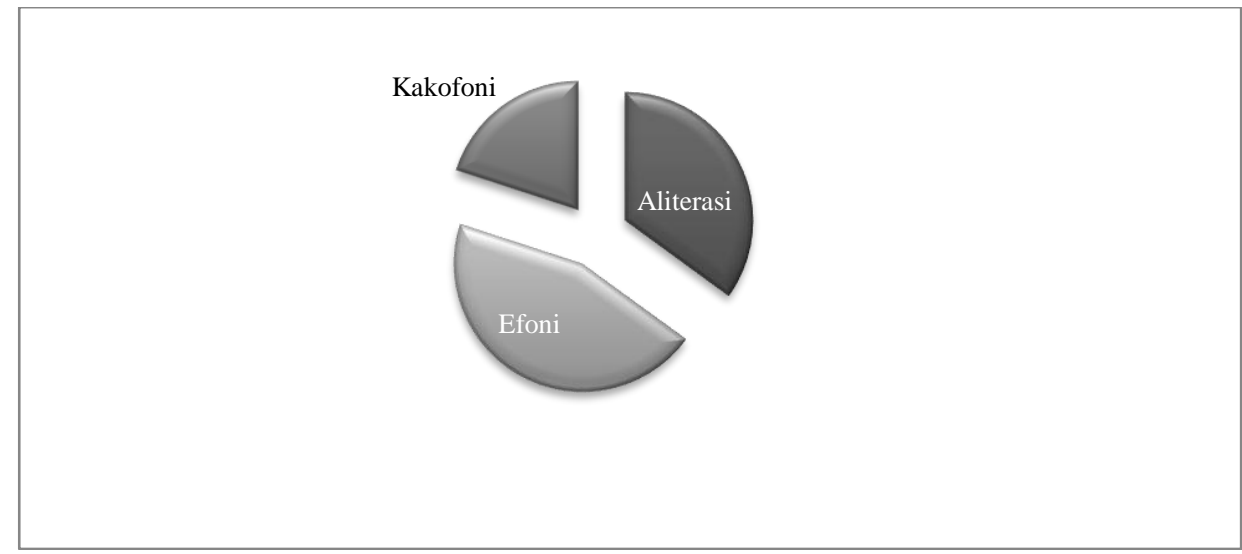

\section{Gambar 2 Diagram Musikalitas Lirik Kawih Kiliningan Gamelan Klasik Cicih Cangkurileung}

Suasana yang banyak digambarkan dalam album ini yaitu mengenai rasa takut ketika hidup harus bertemu dengan kematian. Suasana tersebut digambarkan dalam lima lagu yang bertemakan religius. Sedangkan dalam tema kasih sayang digambarkan suasana yang sedih karena putus cinta dan jauh dari orang yang disayangi. Untuk tema gembira walaupun terasa sindirannya dapat dilihat dalam lagu Sapuluh Daun. Lagu ini merupakan satusatunya yang mempunyai suasana berbeda dari lirik yang lainnya. Hal ini diakrenakan isi lirik menggambarkan kesenangan dan rasa sukur.
Rasa bahagia dan sukur dalam lirik Sapuluh Daun terkadang terasa menjadi sindiran ketika dunungan harus banyak berterimakasih kepada seniman. Hal ini dikarenakan seniman banyak yang tertipu dan dirugikan oleh banyaknya produser yang memeras kreativitas seniman. Seniman hanya dijadikan menghasilkan finansial. Sedangkan ketika lagu yang dibawakan sukses di pasaran seniman hanya bisa gigit jari karena tidak mendapatkan hasil. Dari gambaran di atas, bisa kita lihat paparan suasana pada gambar 3.

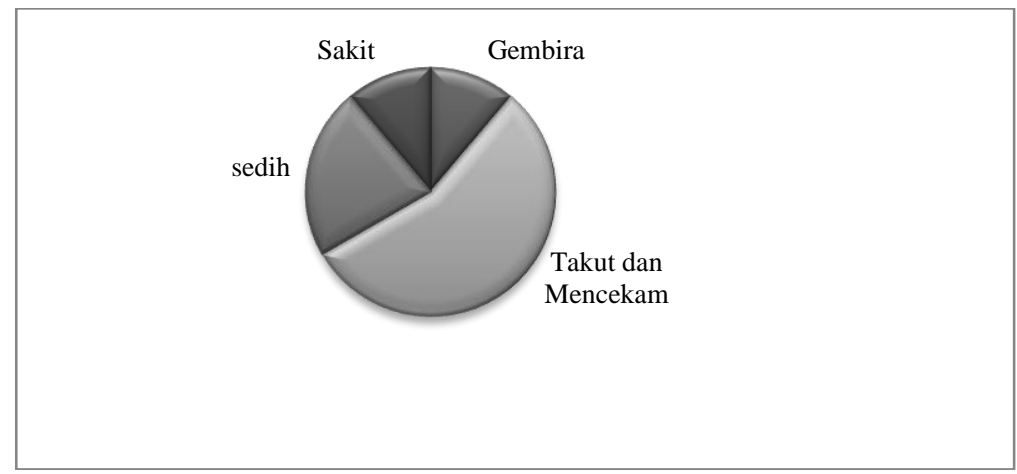

Gambar 3 Diagram Suasana Lirik Kawih Kiliningan Gamelan Klasik Cicih Cangkurileung 
Suasana takut dan mecekam banyak ditemukan dalam album ini dikarenakan dalam rumpaka yang bertemakan keagamaan banyak membahas perilaku manusia dan akibatnya. Segala hal yang dilakukan oleh manusia pasti akan berujung pada pembalasan di akhirat.

Tema yang diangkat dalam album ini banyak mengangkat perkara agama. Dalam lagu Balébat Iman, dibahas mengenai penggunaan harta oleh manusia. Lagu Jatining Hirup dan Karumaosan membahas prilaku manusia dan semua nikmat dari Tuhan yang terasa maupun yang tidak terasa. Nikmat Duriat dan Pucuk Camara témanya mengenai kasih sayang, dan rumpaka Sapuluh Daun menceritakan tentang kreatifitas seorang seniman dalam menciptakan lagu.dari tema yang dibahas, lagu yang paling berbeda adalah lagu Sapuluh Daun. Meskipun katakata yang digunakan merupakan bahasa sehari-hari, tetapi tema yang diangkat bukan tema yang umum diangkat dalam album, melainkan pengalaman pribadi pengarang. Mengangkat kreativitas seniman dalam sebuah lirik tentunya sangat jarang sekali ada dalam sebuah lagu. Malahan ada lebihnya, yaitu memberikan sindiran kepada dunungan yang dalam hal ini menggambarkan sang pemilik modal yang biasa memanfaatkan kreativitas seniman demi keuntungan pribadi. Tema yang ada dalam lirik ini bisa dilihat pada gambar 4 .

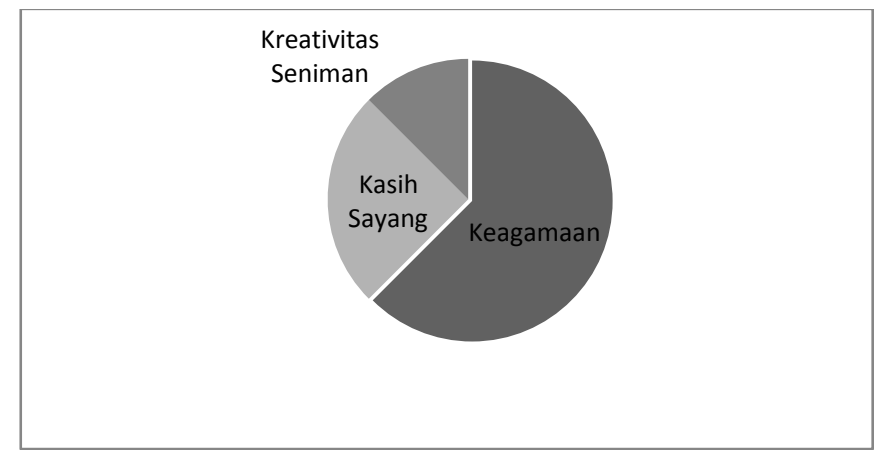

\section{Gambar 4 Diagram Tema Lirik Kawih Kiliningan Gamelan Klasik Cicih Cangkurileung}

Dalam gambaran diagram di atas terlihat bagaimana dominannya tema keagama an. Walaupun dari beberapa lirik membahas aturan agama secara spesifik, tetapi ketika ditarik seimpulan secara umum, tema keagamaan banyak tertera dalam album ini. Dari delapan album, lima di antaranya membahas mengenai aturan agama.

Gaya bahasa dalam album ini sebetulnya menggunakan gaya yang langsung pada maksudnya. Misalnya menceritakan perkara keagamaan, langsung pada intinya. Beberapa materi lirik ada juga yang menggunakan bahasa kiasan yaitu lirik Samoja Bodas dan Pucuk Camara. Dalam lirik Pucuk Camara, sangatlah terasa kepiawaian pengarang dalam membungkus makna hingga sedemikian rupa. Adapun tujuan intinnya yaitu ingin menyampaikan rasa kangen pada sang pujaan hati melalui lagu. Rasa yang disampaikan melalui kiasan suasana malam yang sepi. Ini tentu menjadi hal yang menjadi perhatian pembaca karena bahasa yang dipakai perlu dipahami secara mendalam maksud dan tujuannya. Gambaran gaya bahasa yang ada dalam album bisa dilihat pada gambar 5 . 


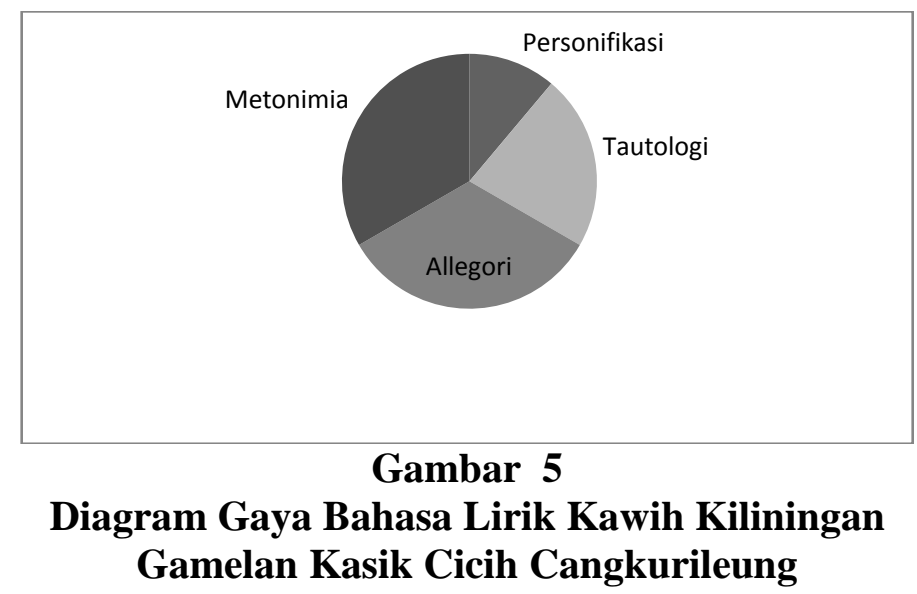

Pada diagram di atas bisa terlihat bahwa gaya bahasa yang dipakai hampir seimbang antara metonimia, allegori dan tautologi. Hal ini dikarenakan dari beberapa lirik banyak terdapat kata-kata yang kembali diulang. Tujuannya agar lebih mementapkan lagi maksud yang diutarakan.

\section{Hasil Analisis Semiotik}

Semiotik merupakan ilmu yang mempelajari tanda. Dalam membahas tanda yang ada dalam lirik kawih kliningan ini, digunakan semiotik pancacuriga. Menurut Suryalaga (2009, hal. 68), pancacuriga merupakan lima alat (ilmu) untuk memaknai satu hal. Adapun lima alat tersebut adalah silib, sindir, simbol, siloka dan sasmita.

Berdasarkan hasil analisis semiotik pancacuriga dalam album Gamelan Kelasik Cicih Cangkurileung, terdapat beberapa hal yang harus dibahas mengenai isi dalam lirik yang tidak bisa dijelaskan dalam analisis. Hal ini berhubungan dengan hasil analisis serta interpretasi di lingkungan masyarakat. Oleh sebab itu, melalui bahasan ini akan dijelaskan mengenai hasil analisis dan apa saja yang berhubungan dengan kehidupan seharihari.

Silib yang ditemukan dalam lirik lagu ini lebih banyak mengandung unsur ajaran agama. Dalam lirik lagu Balébat Iman bahasan utamanya yaitu menjelaskan tentang harta benda yang harus dipakai di jalan Allah. Sebagaimana diterangkan dalam Al-Quran Surat al-Hadid ayat 07 (Al Amin, 2003) yang intinya menyebutkan jika kita beriman kepada Allah, maka sebagian harta kita harus diinfakan. Pada zaman sekarang banyak manusia yang mengumpulkan hartanya, tetapi mereka tidak mau bersedekah. Padahal, jika kita mau memberi sebagian harta kita maka harta kita akan bertambah. Harta hanya sebagai titipan, tapi banyak manusia yang tidak sadar akan hal tersebut.

\section{Lirik lagu Jatining Hirup} menceritakan tentang perkelanaan hidup manusia di alam dunia, tapi dia lupa akan alam akhir yaitu akhirat. Manusia diberi nikmat pancaindra untuk beribadah kepada Allah. Tapi terkadang mereka lupa kepada yang memberi nikmat tersebut, tidak jarang banyak yang menjadi takabur. Padahal jelas diterangkan dalam Q.S. AnNahal ayat 23 (Al Amin, 2003) yang menyebutkan bahwa sesungguhnya Allah tidak menyukai orang yang sombong (takabur). Segala nikmat yang ada di dunia semata-mata hanya titipan Allah semata. Oleh sebab itu, kita sebagai manusia harus menyadari hal tersebut.

Berbeda dengan lirik lagu Jatining Hirup, lirik lagu Karumaosan menjelaskan tentang kesederhanaan manusia yang hidup di alam dunia dan sadar akan kehidupan yang tidak lepas dari salah dan dosa. Sebagaimana dijelaskan dalam Q.S. Al- 
Baqarah ayat 216 (Al Amin, 2003) yang intinya menyebutkan jika kamu tidak menyukai suatu hal, padahal itu baik bagimu, dan boleh jadi kamu menyukai suatu hal, padahal itu tidak baik bagimu. Allah mengetahui, sedangkan kamu tidak mengetahui. Dari isi ayat tersebut, bisa kita lihat bahwa segala sesuatu yang berhubungan dengan kehidupan, kita pasrahkan kepada Allah sebagai yang Maha Kuasa, kita sebagai manusia hanya bisa berserah diri kepada-Nya.

Mengenai peringatan tentang kematian terdapat pula dalam lirik lagu Samoja Bodas. Isi dari lirik lagu tersebut menggambarkan tentang kematian, dimana hakikatnya semua manusia tidak akan siap menghadapi kematian, kecuali mereka yang beramal baik. Oleh sebab itu, isi dari lirik lagu ini memberikan peringatan kepada semua yang mendengar dan membaca agar berbuat kebaikan untuk bekal nanti di akhirat.

Dalam lirik lagu Rukun Iman, terdapat silib yang menjelaskan bahwa kita harus percayaa terhadap rukun iman yang merupakan dasar pondasi dalam diri setiap manusia. Keimanan manusia wajib ada supaya hidup kita tentram. Sebagaimana dalam Q.S. An-Nisa ayat 136-139 (Al Amin, 2003) yang intinya menerangkan bahwa kita harus yakin dan beriman terhadap rukun iman. Jika kita tidak percaya terhadap hal tersebut maka kita termasuk orang yang kafir dan tetmasuk orang yang tidak percaya akan keberadaan Allah Swt.

Dalam lirik lagu pucuk camara, terdapat peringatan yang menjelaskan supaya kita harus sabar dalam memperjuangkan kasih sayang. Meskipun dalam kenyataannya banyak sekali godaan untuk memperjuagkannya tapi, jika kita sabar dalam memperjuangkan kasih sayang tersebut maka suatu saat akan indah dengan sendirinya. Keyainan seperti itu harus tertanam dalam diri setiap orang agar kasih sayang kita terhadap pasangan akan terus terjaga.

Sindir yang terdapat dalam lirik lagu Sapuluh Daun menggambarkan kebahagiaan seniman yang menciptakan lagu secara beramai-ramai. Akan tetapi ada hal yang membuat miris, ketika para seniman tersebut banyak ditipu oleh produser dalam hal pembagian hasil keuntungan penjualan karya. Terkadang para seniman tersebut hanya bisa gigit jari karena mereka tidak menikmati hasil dari jerih payah mereka. Selain itu, kasus pembajakan juga menjadi hal yang sangat merugikan bagi para seniman.

Siloka dan sasmita dari delapan lagu tersebut menjadi hal yang sangat penting. Contohnya dalam lagu Jatining Hirup. Hidup merupakan siloka dari perjalanan sementara sebelum kita kembali kepembaringan. Tentunya dalam perjalanan untuk menuju pembaringan kita harus mempunyai bekal. Tiada lain bekal untuk kita kembali kepembaringan adalah amal baik selama kita hidup di alam dunia.

Sasmita ditemukan dalam lirik lagu Samoja Bodas. Samoja yang tumbuh di pemakaman seolah-olah melambai menjadi isarat bagi manusia yang ditunggu oleh kematian. Manusia hanya tinggal menunggu kapan giliran mereka kembali kealam keabadian. Sedangkan mati menjadi isarat dimana manusia akan melanjutkan kehidupannya di alam sesudah kematian.

Agar lebih mudah, secara umum bahasan semiotik pancacuriga, digambarkan melalui diagram. Ada pun diagram hasil penelitian ini bisa dilihat pada gambar 6 . 


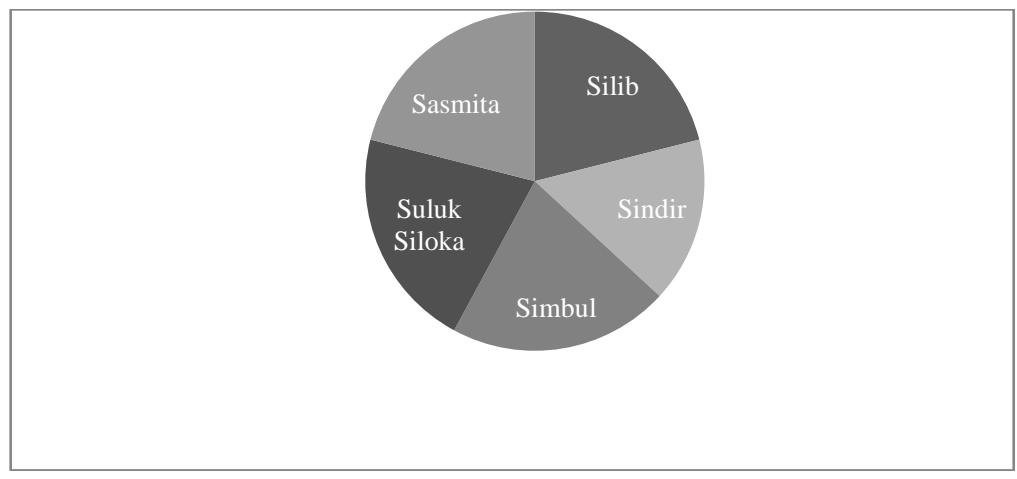

\section{Gambar 6 \\ Gambaran Tilikan Semiotik Lirik Kawih Kliningan Gamelan Klasik Cicih Cangkurileung}

Dalam gambar grafik di atas, bisa disimpulkan sindir menjadi unsur semiotik paling sedikit. Hal ini disebabkan karena sindir hanya terdapat dalam beberapa lirik lagu. Lain halnya dengan silib yang menjadi unsur semiotik paling banyak. Dalam isi lirik terdapat banyak sekali peringantan (pépéling) dan pepatah untuk dijadikan cerminan dan contoh dalam kehidupan sehari-hari.

\section{Hasil Analisis Etnopedagogik}

Etnopedagogik adalah ilmu yang berdasar pada budaya dan adat kebiasaan masyarakat yang harus dilestarikan, agar maju dan berkembang, dan mewujudkan kehidupan yang unggul (Ruhaliah, 2015, kc 45). Dalam etnopedagogik, digunakan analisis melalui pembentukan karakter manusia Sunda yang pengkuh agamana, jembar budayana, luhung élmuna, dan rancagé gawéna (Moriyama, 2015, hal. 121). Penjabarannya melalui moral kemanusiaan. Adapun moral kemanusiaan yang dimaksud adalah moral manusia kepada Tuhannya, moral manusia terhadap alam, moral manusia terhadap pribadinya, moral manusia terhadap waktu, moral manusia kepada manusia lainnya, dan moral manusia dalam mencapai kepuasan lahir batin.

Berdasarkan hasil analisis etnopedagogik lirik kawih kiliningan Gamelan Klasik Cicih
Cangkurileung,banyak hal yang ditemikan terutama untuk menjadi cerminan dalam kehidupan orang Sunda pada masa kini. Adapun yang menjadi inti dalam penelitian ini yaitu moral manusa yang saat ini sudah lupa pada asalnya. Manusia sudah jauh dengan Tuhannya. Oleh karena itu, perlu adanya usaha untuk menggali nilai-nilai yang ada pada karya sastra yang pada hal ini adalah lirik kawih kliningan agar bisa menjadi tuntunan hidup.

Moral manusia pada tuhannya banyak ditemukan pada rumpaka yang bertemakan keagamaan. Pada rumpaka Balébat Iman, Jatining Hirup, Karumaosan, Rukun Iman, dan Samoja Bodas, moral manusia terhadap tuhannya sangat jelas terlihat. Adanya kata Gusti, Ilahi dan Pangéran, merupakan gambaran Allah SWT. Pada setiap lirik diterangkan mengenai manusia yang taat pada perintah Allah. Manusia harus menghindari hal-hal yang dilarang oleh Allah SWT dan harus menjalankan perintahnya agar manusia berada di jalan yang benar. Mengenai kewajiban manusia agar taat pada perintah Allah diesebutkan dalam Q.S. Al-Anfal yang berbunyi bahwa kita harus taat kepada Allah dan Rosulnya apabila kita orang-orang yang beriman.

Moral manusia kepada alam terlihat pada lirik Rukun Imanyang menggabarkan perkara hari kiamat. Gambaran hari kiamat diterangkan di dalam Q.S. Al-Qiyaamah 
(Al Amin, 2003). Dalam surat ini diterangkan bagaimana mengerikannya hari akhir tersebut, di mana manusia tidak bisa lagi lari dari hari akhir ini.

Moral manusia kepada pribadinya terlihat pada lirik Karumaosan. Dalam lirik ini digambarkan bagaimana pasrahnya seorang manusia terhadap Tuhannya. Di setiap baitnya menggambarkan pertanyaankepada diri sendiri mengenai keimana dan segala dosa yang dilakukan. Tentunya hal ini sangatlah baik untuk menjadi muhasabah. Dengan seringnya manusia bermuhasabah tentu akan menjauhkan dirinya dari perbuatanperbuatan tercela.

Membangun kepribadian yang baik tentunya menjadi hal yang utama untuk manusia. Baik secara fisik, maupun secara rohani. Perilaku yang disenangi akan menjadi modal untuk hidup di masyarakat. Untuk orang Sunda, menjadi manusia yang cageur, bageur, bener, pinter, singer tur pangger adalah tujuan utama dalam hidup. Manusia yang terampil dalam segala hal tentulah tidak akan sulit dalam hidupnya karena mempunyai keterampilan yang mumpuni.

Moral manusia kepada manusia lainnya terlihat pada lirik yang bertemakan tentang keagamaan.selain itu, inti dari moral manusia terhadap manusia lainnya terlihat pada lirik Rukun Iman. Isi dari lirik ini membahas mengenai iman kepada Rosul Allah menggambarkan bahwa kita harus meneladani sifat wajib Rosul yang benar, dapat dipercaya, menyampaikan dan pintar. Dari sifat yang dapat amanah atau dapat dipercaya, bisa menjadi modal yang dimiliki manusia untuk hidup berdampingan di masyarakat.

Sikap amanah diterangkan dalam Q.S. Al-Anfal ayat 27 (Al Amin, 2003) yang berbunyi bahwa kita tidak boleh berkhianat kepada Allah dan Rosul (muhammad) dan janganlah berkhianat terhadap amanat yang dipercayakan. Berkaca dari ayat tersebut, tentunya sikap amanah tersebut bukanlah sikap yang mudah untuk diwujudkan. Terkadang di jaman sekarang ini banyak ditemukan pemimpin yang tidak amanah dalam mengemban jabatannya. Sedangkan jabatan tersebut menyangkut hajat hidup orang banyak. Banyak pemimpin yang tidak amanah yang mengakibatkan rakyat sengsara.

Moral manusia terhadap waktu terlihat dalam lirik Samoja Bodas. Lirik ini menceritakan perkara kematian yang bakal menimpa semua makhluk yang hidup di dunia. Waktu hidup di dunia adalah waktu yang sangat baik untuk beribadah. Sebagaimana diterangkan dalam surat AlAsr perkara waktu. Dalam surat ini diterangkan bahwa sesungguhnya manusia berada dalam kerugian. Melainkan yang beriman dan yang beramal soleh yang saling memberi wasiat dalam kebenaran dan kesabaran. Pada surat tersebut jelas diterangkan bahwa manusia yang merugi adalah dirinya yang banyak membuang waktu.

Moral manusia untuk mencapai kepuasan lahir batin terselubung dalam lirik yang mempunyai tema religi, seperti Balébat Iman, Jatining Hirup, Karumaosan, Rukun Iman dan Samoja Bodas. Kebahagiaan lahir batin yang digambarkan dari lima lirik ini yaitu ketika manusia berpulang ke pangkuan Ilahi dengan membawa amal baik.

Dalam lirik Balébat Iman, kebaikan yang dilakukan dalam kehidupan seharihariyaitu ketika kita mendapatkan harta yang berlebih digunakan untuk sedekah. Harta yang kita miliki harus dipakai untuk bera,al agar menjadi ladang pahala untuk kita. Harta yang dititipkan kepada kita jangan sampai dipakai untuk masiat.

Dalam membangun diri untuk menjadi insan yang mandiri serta memiliki akhlak yang baik tergambarkan dalam lirik Jatining Hirup jeung Karumaosan. Dalam lirik tersebut, banyak pepatah agar diri kita menjadi manusia yang mempunyai perilaku baik. Hal-hal yang buruk perlu 
dihindarkan agar kita dijauhkan dari siksa Allah SWT.

Rukun Iman sebagai petunjuk hidup harus diyakini oleh kita dan diamalkan dalam kehidupan sehari-hari. Banyak yang bisa gdigali dalam rukun iman untuk cerminan hidup kita. Seandainya pepatah dan petunjuk tersebut kita laksanakan, ketakutan kita ketika berpulang ke
pangkuanNya tidak akan terlaku menakutkan seperti dalam gambaran lirik Samoja Bodas.

Agar lebih jelas dalam bahansanya, perlu adanya gambaran tilikan etnopedagogik dalam bentu diagram. Gambaran tilikan etnopedagogik mengenai moral kemanusiaan dalam bentuk diagram bisa dilihat pada gambar 7 .

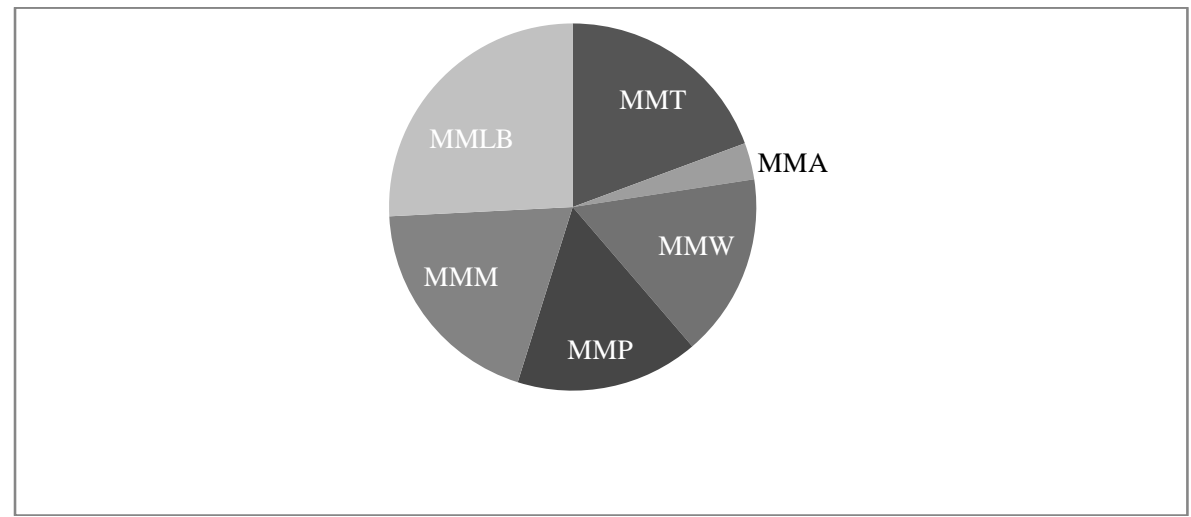

Gambar 7

Diagram Tilikan Etnopedagogik Lirik Kawih Kiliningan

Gamelan Klasik Cicih Cangkurileung

Pada gambaran diagram di atas terlihat bahwa moral manusia untuk menggapai kepuasan lahir batin banyak terlihat di setiap lirik. Hal ini dikarenakan pada setiap lirik membahas perkara manusia dan semua hal yang dilakukannya, terutama hal yang memang disukai. Segala tujuan lirik ini tiada lain untuk menggapai kepuasan lahir batin yang digambarkan oleh perilaku bermunajat pada Allah, hati tenang, hidup rukun, menyayangi sesama, dan lain sebagainya.

Sebenarnya, apabila digambarkan, moral manusia terhadap Tuhannya adalah moral yang paling utama. Hal tersebut bisa dilihat pada gambar 8 .

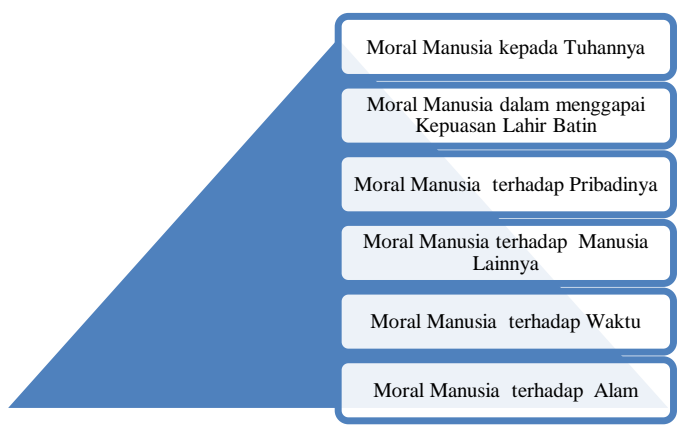

Gambar 8

Tingkatan Moral Manusia 
Pada gambar 8 digambarkan bagaimana posisi moral manusia. Moral manusia pada Tuhannya menduduki posisi tertinggi lantaran apa yang ada dalam lirik lagu album Gamelan Klasik Cicih Cangkurileung memiliki satu tujuan yaitu beribadah kepada Allah SWT. Oleh karena itu, posisi moral manusia terhadap Tuhannya menduduki posisi tertinggi.

\section{SIMPULAN}

Dari hasil analisis struktur, ditemukan téma secara umum dalam album ini yaitu mengenai keagamaan. Meskipun ada dua lagu yang berbeda tema, tapi secara umum tema keagamaan banyak ditemukan dalam album ini.

Untuk tanda yang ada dalam lirik, ditemukan pepatah untuk diterapkan dalam kehidupan sehari-hari. Adapun pepatah yang dimaksud adalah mengenai (1) pepatah agar mau saling memberi dan menggunakan harta di jalan yang benar, (2) pepatah agar menjadi pribadi yang selalu patuh pada perintah agama, (3) pepatah untuk mengamalkan rukun iman, (4) pepatah agar setia, (5) pepatah agar mengingat kematian, dan (6) pepatah agar saling menghargai kepada orang lain. Tentunya pepatah tersebut sangatlah baik untuk diterapkan dalam kehidupan seharihari.

Untuk nilai-nilai etnopedagogik, moral manusia terhadap tuhannya menjadi hal yang utama. Hal tersebut didukung pula dengan keberadaan moral yang lainnya, guna mencapai tujuan menjadikan manusia Sunda yang pengkuh agamana, jembar budayana, luhung élmuna, dan rancagé gawéna.

\section{PUSTAKA RUJUKAN}

Afryanto, Suhendi. (2014). Seni Gamelan dan Pendidikan Nilai. Bandung: Sunan Ambu Press.

Al Amin Quran Terjemah Sunda. Shaleh, Qamaruddin, dkk. 2003. Bandung: Diponogoro.
Danadibrata, R.A. (2006). Kamus Basa Sunda. Bandung: Kiblat Buku Utama.

Fathoni, Abdurrahmat. (2006). Metode Penelitian dan Teknik Penyusunan Skripsi. Jakarta: Rineka Cipta.

Hendrayana, Dian. (2014). "Mendudukkan Istilah Kawih dan Tembang dalam Pengajaran". Dalam Didi Sukyadi \& Yadi Mulyadi (Editor), Prosiding Forum Ilmiah $X$ (Seminar dan Lokakarya Internasional Bahasa, Sastra, Seni dan Pembelajarannya) "Kajian-kajian Mutakhir dalam Bahasa, Sastra, Seni dan Pembelajarannya untuk Memperkokoh Jati Diri Bangsa” (Kc. 34-39). Bandung: FPBS UPI.

Hernawan, Dedy. (2003). Pengantar Karawitan Sunda. Bandung: Pusat Penelitian dan Pengembangan Pendidikan Seni Tradisional (P4ST) UPI.

Isnendes, Retty. (2010). Teori Sastra. Bandung: JPBD FPBS UPI.

Kurniawan, Aris. (2014). "Kajian Historis dan Filosofis Kujang”. Jurnal Itenas Rekarupa.Pp.1-40.

Moriyama, Mikihiro. (2015). "Perbandingan Pendidikan Karakter antara Daerah Sunda di Indonesia dan Jepang". Dalam Ruhaliah (Editor). Pendidikan Karakter dalam Budaya Sunda dan Jepang: Sebuah Kajian Perbandingan (Character Education in the Sundanese and Japanese Cultures: A Comparating Study) (Kc.110-125). Bandung: Universitas Pendidikan Indonesia.

Mustappa, Abdullah. (2014). Wirahma Sajak. Jakarta: Pustaka jaya.

Ruhaliah. (2015). "Pendidikan Karakter dalam Sastra Sunda Klasik". Dalam Ruhaliah (Editor). Pendidikan Karakter dalam Budaya Sunda dan Jepang: Sebuah Kajian Perbandingan 
(Character Education in the Sundanese and Japanese Cultures: A Comparating Study) (Kc.41-61). Bandung: Universitas Pendidikan Indonesia.

Suryalaga, Hidayat. (2009). Kasundaan Rawayan Jati. Bandung: Yayasan Nur Hidayah.

Tamsyah, Budi Rahayu. (1996). Pangajaran Basa Sunda. Bandung: CV. Pustaka Setia.

\section{UCAPAN TERIMA KASIH}

Penulis mengucapkan terimakasih kepada berbagai pihak yang telah membantu dalam penelitian dan penulisan artikel ini, baik kepada pemerintahan, masyarakat, teman sejawat, maupun para mahasiswa Pendidikan Bahasa dan Budaya Sunda UPI. Ucapan terimakasih terutama saya ucapkan kepada keluarga Alm. Ibu Cicih Cangkurileung dan simpatisan seniman yang turut serta mendukung selesainya artikel ini. 